我が民生と羊毛產業の前途

前 が 立岩

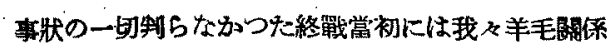
者の中でも敗戰日本の將來果して我々が綪物な゙゙の

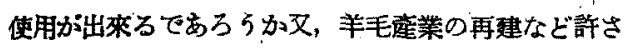

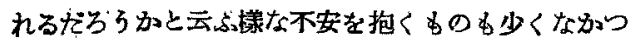

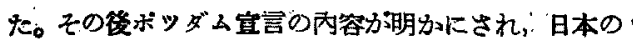

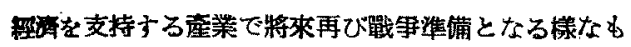
のでない限り，その維持が許され又これに必要な愿料

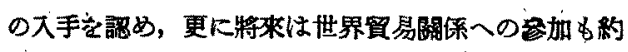
束されて居ることを知つた。しがこの宣言は連合軍

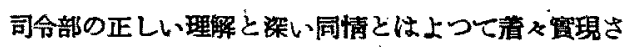
れて行方，我为民生に这要な羊毛製品の使用に部いて

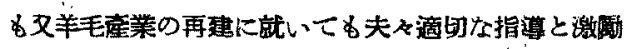
とか與へられて居り，我心铝係者としては洵に明、氣

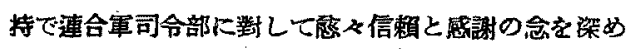
て居る第である。

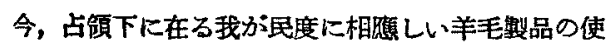
用限度と加又にれ補給の手段乃至特來世界貿易一鲁加

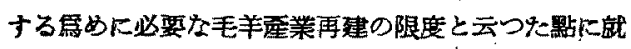

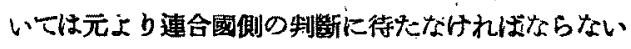
のであるがこれらの點に䣌、て我々の誠意ある意圆

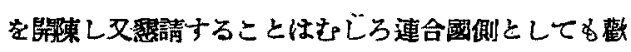
迎されることと信ずる。そこで我か尼生と羊毛竰業の.

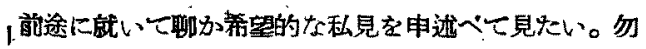
論此の樣な問題に㹌いては色々の考へ方があると思ら，

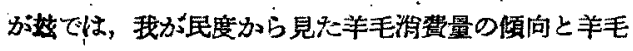

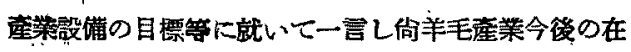
方と云つた點に一二触れて見たいと思よ。

\section{1. 過去に於ける我が羊毛事将}

我为國沪羊毛㸞品の渡來したのは果して何時の頃で あつたのか、难それがどんな風に利用されて来たのか

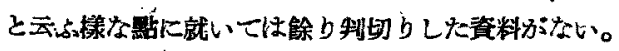

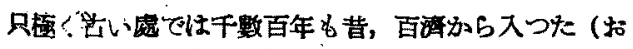

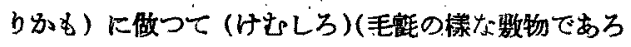
’らとの事) を織つたと云ら事である。その後千叙年，

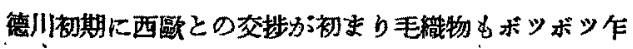

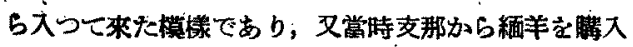

幸等

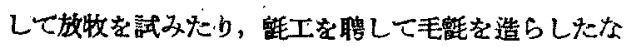
どの事も傳へられて居る。德川中期, 武家の使用した 陳旸織とか犬小の刀弝俌などに緋や淺黄, 白などの立 派な羅秒を使用して居た事加ら推して既下當特かなり 閎く珍重されて居たものと考一られる。何れ正式に多 鼠交易されれ出したのはベルリ提督に上る開國後の事で あ万5か，明治初年の毛織物输入高が我か;總輸入高の 二割內外を占めて居を事から推して毛織物は我が民生 に梁く险い入つて居を事が立證されると思ふ。

明治維新政府涫官宾，兵制，警察等の諸制度とその 服裝とを制定してがら毛織物の需要は䈐しく增大して 來大ののて早くもこれが踥策として牧羊事業と羅紗製造

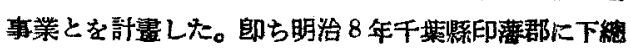
縝羊場を關設して緗羊の咱育を計り，明治 12 年には 東京南千住に羅紗器城所を創設して制服用羅紗，毛布

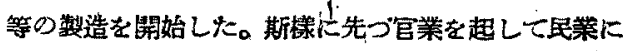
琶籁してから今日迄約 70 年を䦥したに過ぎないが毛

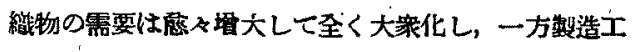

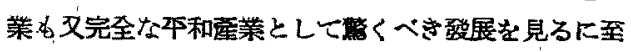
つた。只原料對策である緬羊事業は夾少なる我が風土 的な閶保で到底際洲その他大陸の牧羊事業に追隨する

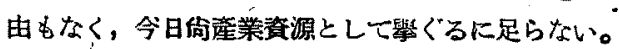
從つて原料羊毛は殆どされを海外に柳がざるを得ない 狀態である。

今この間の羊毛事狀を更に詳說する层がないが此れ

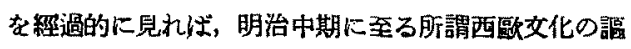
歌㭙代には毛織物用途は殆ど模做洋裝特代であり，製

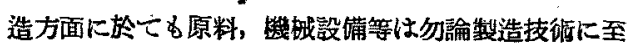
るまで輸入に待たなければなならなかつたのであるか

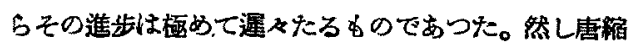

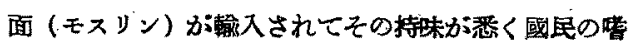
好に投し年太需要加激㒄する虎加東西に大企業的な なモスリン紡織工場が設立され，ついで请尺ャルの考 案は毛織物を完全に和裝化したものと云ひ得へく，た

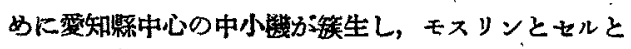

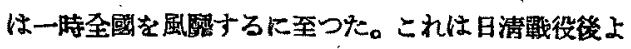
b大正初期に至る約 20 年間め出來事であつた。第 1

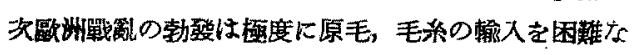

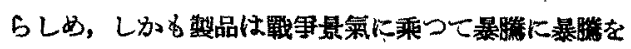




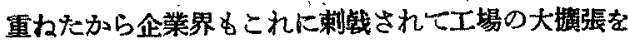

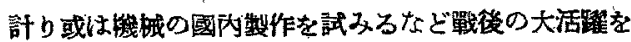
夢みたのである。然し平和來と共に我か財界を嘻らた パニック，ついで閵東大震災，更に大正末期には世界

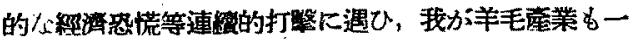
時火の消えた様な不涗に沘淪した。然し此の間羊毛

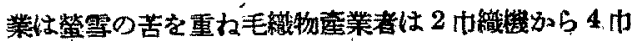

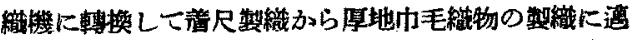

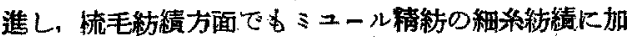

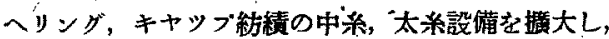

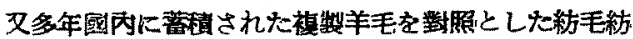
績が各地に設立を見たので妶に毛織物製造の生產能形
を完成し，折柄の但原料低工費の浪に乘 bここに毛織

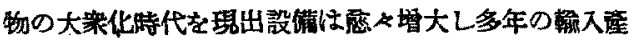

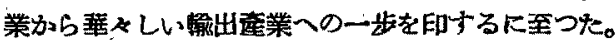
これは炤和の初期 10 年間の事である。昭和 10 年日嫁

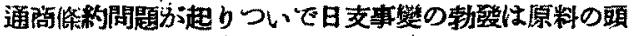
打となりその後戰爭の進さたつれて平和詹業の名の下 に渐次强㗨なる制粎を受け，原料消費の規制，企業緗

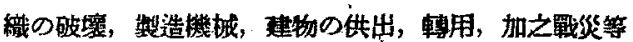

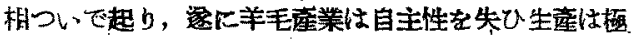

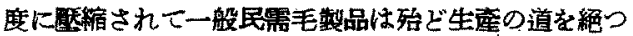
に至つた。

今昭和 5 年以降の羊毛工業設饰推移，立下毛手毛織 物の生㢈高の愈 入高の推移を絡 示亦礼忙国表 1 , 2, 3 の如く厄 市。

\section{2. 民生と} 我名羊毛 消質量の 限度 前節に於こ述 ベを如く我力゙完 生と羊毛とは嚾 为100年間下梁

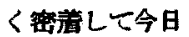
不可倭のあとなつた

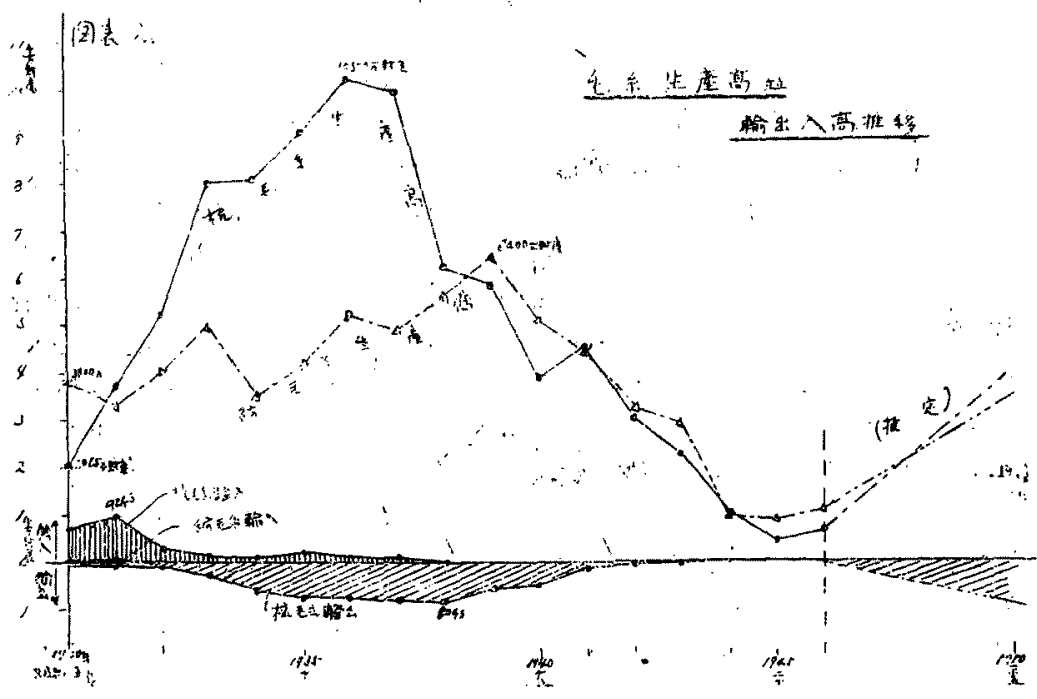
のであるがこれを鴯漣

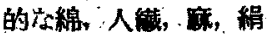

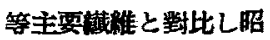
和 5 年以降國宠 1 人 賞りの消素量として示 あせは圆表4の如くで ある。

即古昭和 5 年人口 1 人賞辛毛消量 $1.01 \mathrm{lb}$ (系量換算上下同じ)

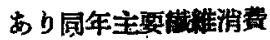
量合詊 $9.52 \mathrm{lb}$ 稀 10.6 \%を示めしてかるが，

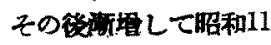
年には丰毛 $1.98 \mathrm{lbs}$ に 達し全唯昌 $13.4 \mathrm{lbs}$ 
に對し 14.4\%となつ\%。然し戰爭突入に上り各䋐維

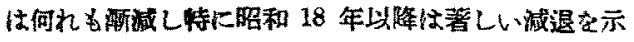
めし我が民生に烍たしい苦涌を與へて居亏事を明かに

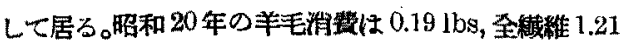

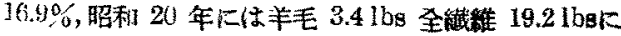

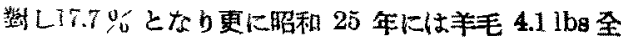

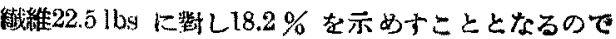
岕。

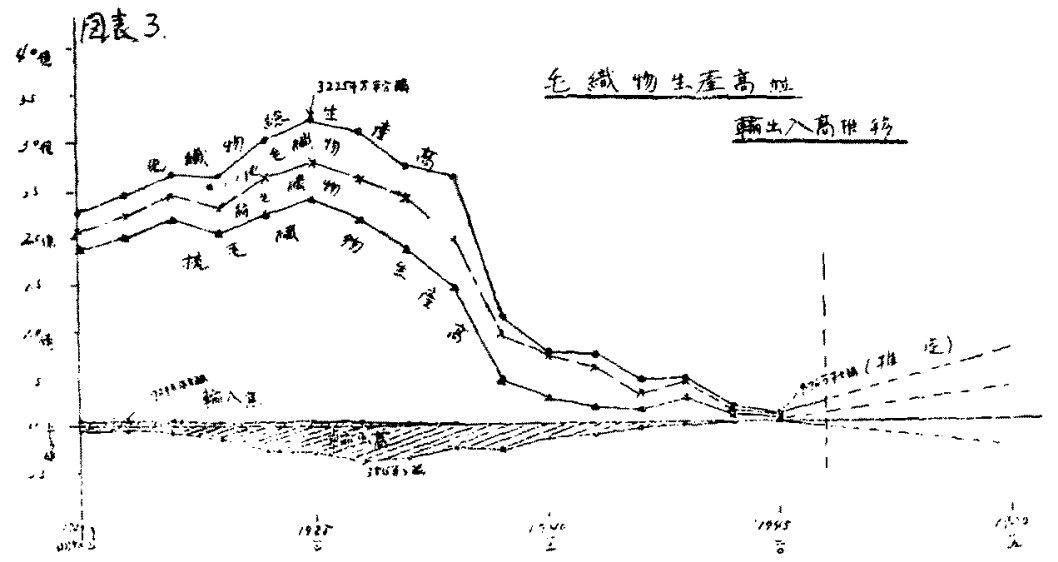

lbsの $15.7 \%$ 示めしてるるが此れ羊毛に於ては昭

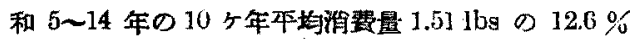

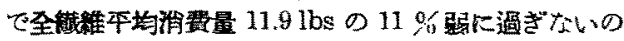
である。かの如く國民の羊毛消费量は極度に減少し たのであるがこの中から更に工業必須資材が愠先的に

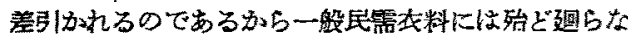
かつたのが事整であつた。國民生活去生死の浮沈裡に

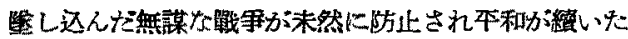

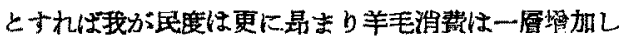

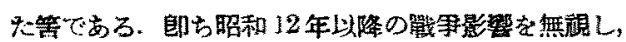

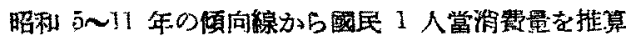

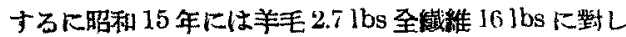

がくの如 數字は一見假定的のものと見られるがこ “れを歌米先進諸國民の緒維消費量に對比すれば必ずし

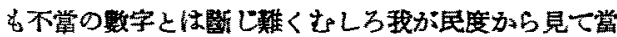

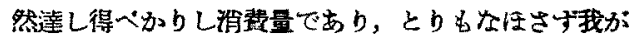
图氐の感情的希求量大示め十百のと考へられる。特に

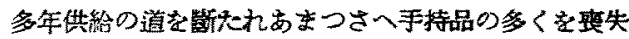

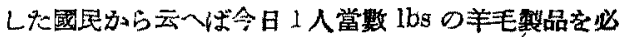
裂とすると五ふる当强ら無理な要求とは云はれない。然 し乍ら我从は敗践の事算を現認し且つ全世界多數の人

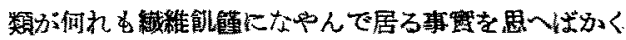

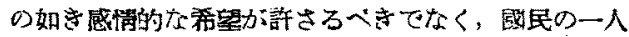

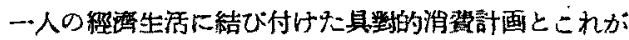

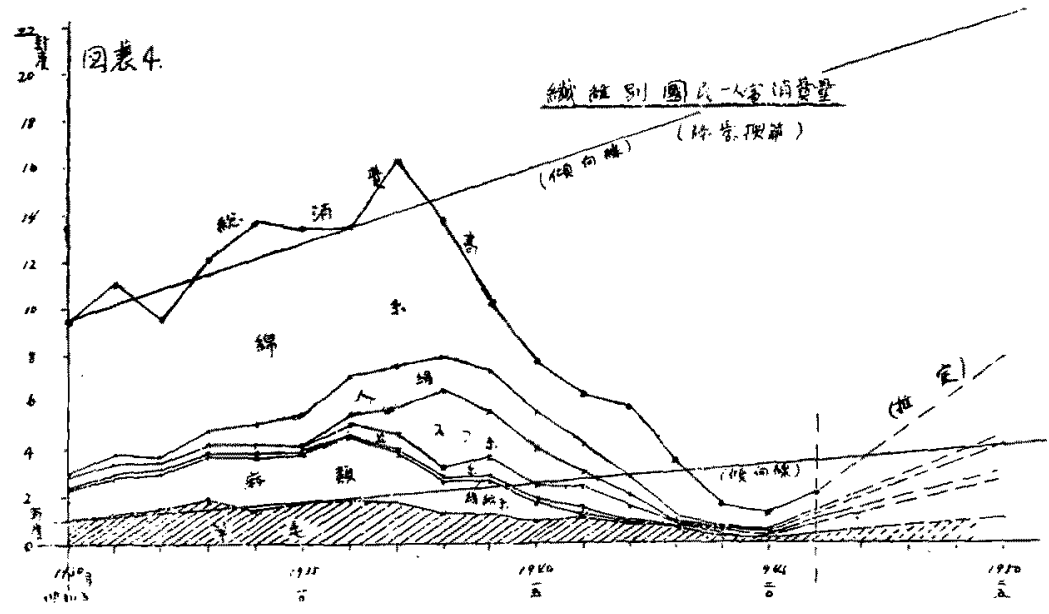


補給の具對的方法をる考慮したものでなければ許され ない。さきにこの様な澺味で民間の總意を盛込んだ緎 維晋業建 3 ケ年計画案が政府に提出され，政府はこ れが連合軍司令部の裁斷に待つて居る。此の計画住勿

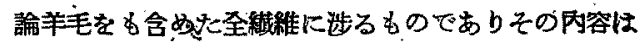
前视の基磨に恢つて立案されたものであるがその具對 的 1 人虽消費量は我々の希望量と凡そ程遠いすので ある。又再建設栭に就いてす甚た心許ない程度のもの である。然し此等は今後 3 ケ年間仁全力を盡して達成 すべ目標を計画したるのであり，現下の网外事状で はこれさへ安易に完成されるとは思はれない。即方斯 程に我が應業の回復力が消䐴されてろるのである。我 タは此の計画はあくまでも 3 ケ年計画であり最後的な 消費限度でなないのであるから我が民度の回復に連れ てやがては國民の希求するが如き羊毛の消費が管現し

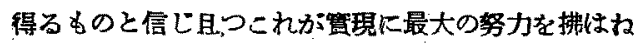
ばならぬと思ら。

\section{、.3. 差毛産業再建の限度}

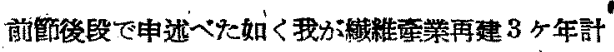

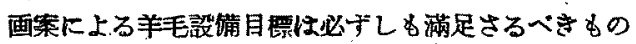
ではないが然为周国の事狀から見て萬全を盤して始め て逆成し得可き程のタのが揭げられて居るに過ぎな

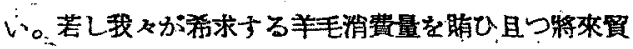
易方面に活躍すべ設備を考虐するならば少くも過去 の設请以上のものが必要とされる。只始に考へねばな

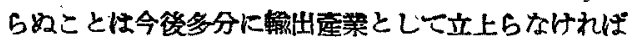

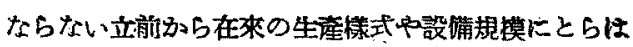
れずにむしろ想を新にした行方で再建方策を立てね ばならぬと思ら。

\section{4. 羊毛痤業今後の剆ひ}

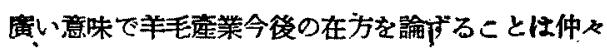

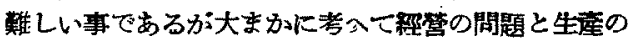

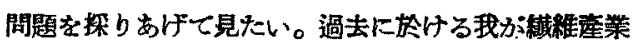

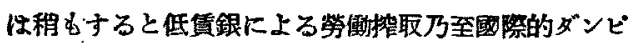
ンクス体つてのみ今日を捷ち得たが如き批制を受け勝 ちであつた。これは羊毛虚の場合必ずしす當つて居 るとは考へない。然し大企業にせよ小企業にせよ独來

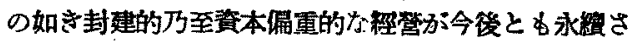
ろべすのでもなく，又國際貿易慧章に逆行する样な ことは許さるべいもない。郎ち內に於いては相互信賴 を基調とした等盗の完全な協力に上る生座意钟の發揮

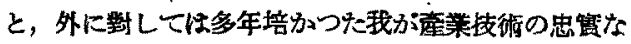

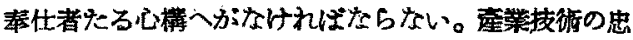

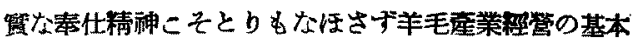
と云へるだろら。

次に生產の問題であるが恕で第1下考へかばならな

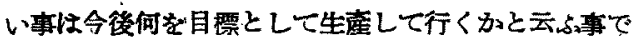
ある。我方國て注永い閻毛蟣物を贵重品扱ひにして來 た即ち生目標も相掌高級品留のものが主であつた。 然し今日では全く大義衣料化したのであるかららすと

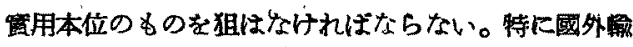
出品目標には英國その他との競合を屖けこことに注意

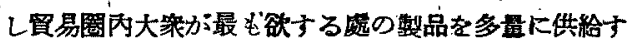
べぎある。第2には原料問題ですつて前述の生耊目 標に極めて關連深いか涐が國で使用して來た羊毛は稍

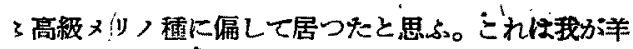

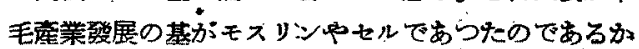

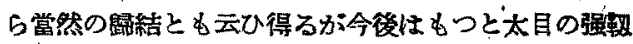
なカムバック級羊毛中或は裾物の利用を訐り，更に䄸 花，スフ其他の䋐維との混紡を礁用する等工夫が要る と思ふ。第 3 下は生産方式の䦗題であるがこれとても

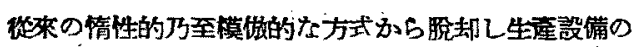

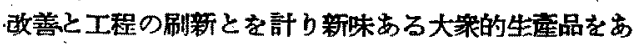
出すことが必要である。

以上羊毛虐業の在方に就いて感した退を卒直代述へ

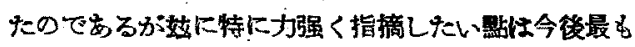
重要な役割を演ずるいの科學接術ですると云ら點で

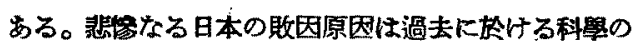
典眥であうたとさへ云はれて居る。此れは强ち科學者 の無氣力をのみせせべきではなく，罵政者や社會が科 覓を西重することを放裹した罪と云はなけれげならな い。とすまれ，技街の票重，技術の訓育蓋成こそは羊

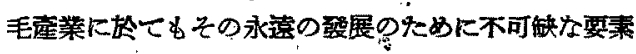
と云はなければならない。

最後に一言附加したい事は國虐羊毛對策である。今

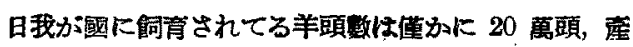

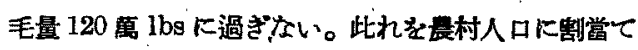

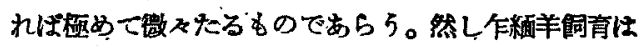

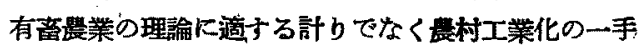
段としてもらつてつけのあのであるから晨村經清合理 化の上から是非と期長有成したいののである。從來 國㘱羊毛は殆ど政府の一手買上であり，羊毛加工に對 ナる指導方策が振はなかつた。現在多くはブローカー

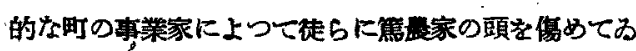
るに過きない。何上りも早く此等の手から银村を主遗 とナる部落單位乃至緬羊組合單位の工業形熊に取り杘 


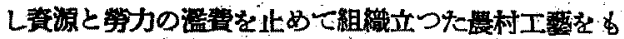

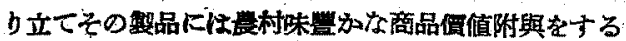
こと老志九てはなならない。为くしてこそ始めて我名 國のホーススバン策が成立し，行くさきざは立瓜な

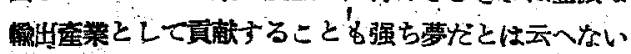
楛35。

\section{5. む す び}

羊毛と我が民生は今日不可缺のすのでり，我が民 力の回復につれて谷！需要の增加が期待されること，

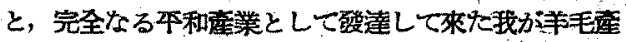

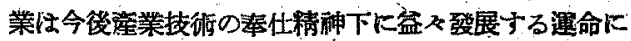

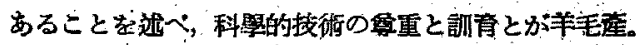
業に於てもその张展のために基本的な要素たあること を述べた次第である。

(昭和 22 年 2 月 20 日)

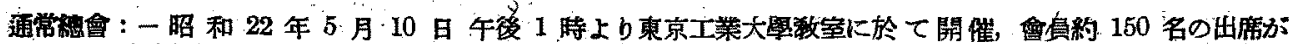

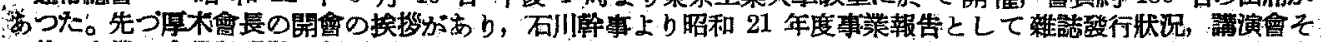

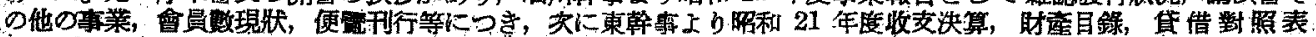

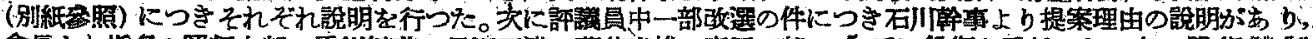

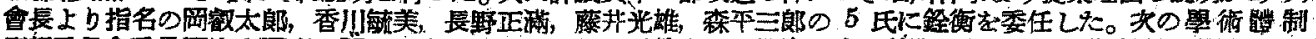

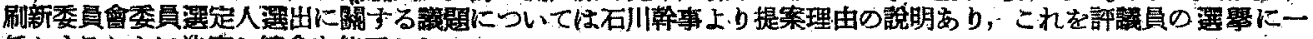
任とすることに決定し螕會を終了した。

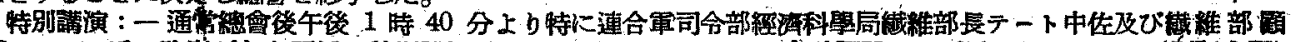

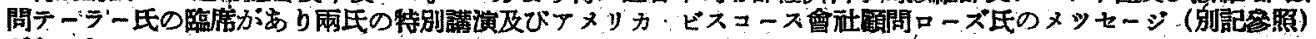
があう大

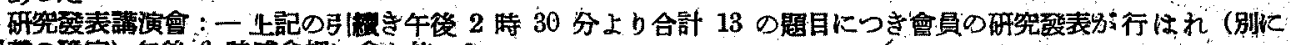

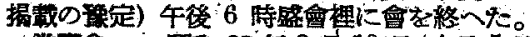

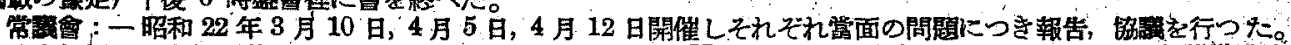

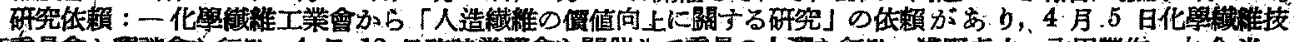

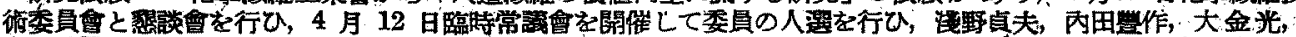

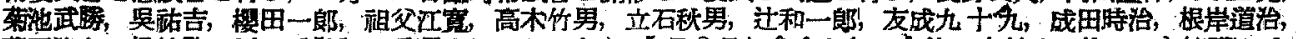

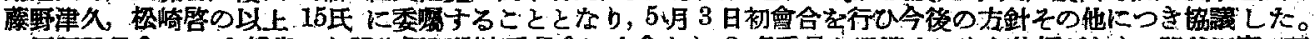

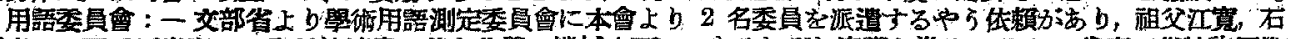

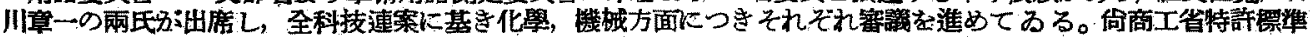
局の工业摽淮用語測定委員會とも密接な連絡をとることつした。

\section{驖維學會第五年度祒莫書}

自昭和 22 年 4 月 1 日 至同 23 年 3 月 31 日

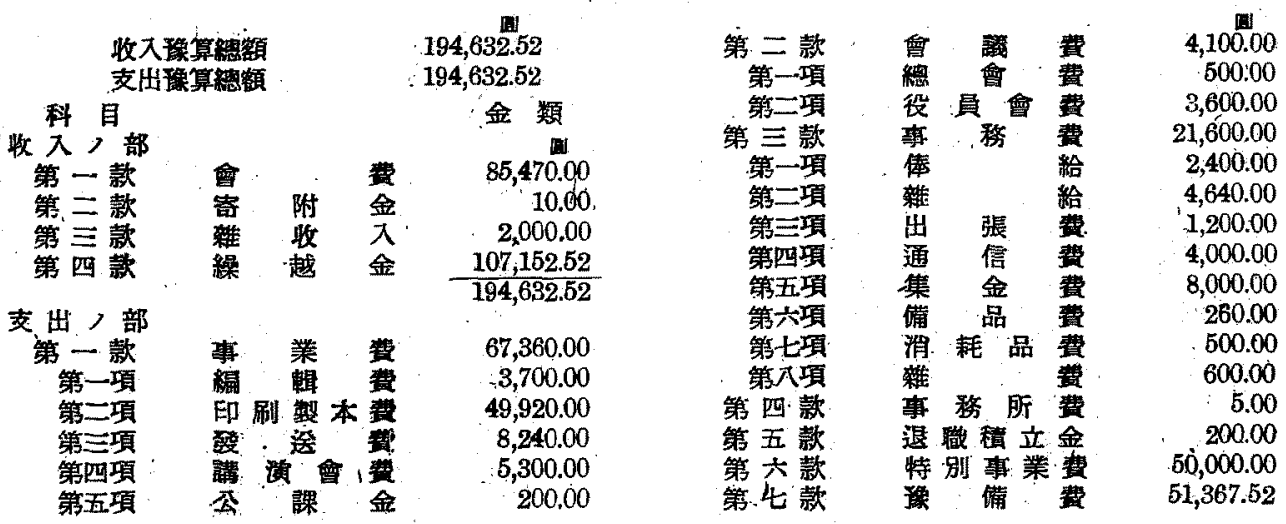

